\title{
Water table evaluation post the construction of canal blocks on peatland in West Kalimantan, Indonesia
}

\author{
Henny Herawati ${ }^{1, *}$, Aji Ali Akbar ${ }^{2}$, Dwi Farastika ${ }^{2}$, and Azmeri ${ }^{3}$ \\ ${ }^{1}$ Civil Engineering, Engineering Faculty, Tanjungpura University, Indonesia \\ ${ }^{2}$ Environmental Engineering, Engineering Faculty, Tanjungpura University, Indonesia \\ ${ }^{3}$ Civil Engineering, Engineering Faculty, Syiah Kuala University, Indonesia
}

\begin{abstract}
Creating canal network is the first step to do agricultural practice in wetlands that aims to make the wetland dry. The existence of canal network affects the hydrological function of peat ecosystem in West Kalimantan which leads to drought and peatland fires during dry season. Canal network on peatlands causes the previously stagnant water to flow out easily through the canal. Therefore, a repressive effort is required to maintain water table in peatland. A countermeasure that has been applied to restore peat is by constructing canal blocks on the established canals. The objective of this study was to assess and evaluate changes in water table in peatlands after the construction of a canal block in Wajok Hilir Village, Mempawah Regency, West Kalimantan. Based on the water table evaluation result on peatland with and without blocked canal, it is identified that peatland surrounding blocked canal had smaller water table fluctuation than the peatland surrounding unblocked canal during 1 tidal period. This research concludes that the construction of canal block helps retain water longer in peatland so that water table can be maintained in short term and is expected to restore hydrological function of peatland in the long term.
\end{abstract}

\section{Introduction}

Agricultural practices are not only performed on dry lands, but also in wetlands. The wetlands discussed are wet peatlands. Activities in the wetlands begin by managing the land to become dry by creating drainage in the form of canal network. Since the 1960s, the wetlands of West Kalimantan Province have begun to be opened independently by Bugis and Malay residents with limited capacity possessed by the community [1]. In the 1970, to support the government's food self-sufficiency program and transmigration program to West Kalimantan, the government began to open up new lands as agricultural land with the construction of drainage canals on peatlands [1]. In addition to its function as a drainage canal, several canals are also built with special functions as boundaries between hamlets in a region [2].

* Corresponding author: hennyherawati@civil.untan.ac.id 
Canal network on peatlands causes the water that naturally exists within peatland to flow freely out of the land through the canal. Uncontrolled canal network development causes excessive drainage (over drain) especially during the dry season. This condition causes the peatlands to experience drought. If the drought persists for a sufficiently long time, irreversible drying conditions may occur. If peatlands reach this condition then the ability of peat to store water will be lost [3]. Over drain may cause changes in peatland characteristics, including land subsidence and changes in water table in peatlands [3][4].

Peat is an organic soil, thus if the peat is in a prolonged dry condition, it will be easily subjected to fire [3] [5]. In 2015, there was a big land fire on peatlands in Indonesia [6], [7], including West Kalimantan Province. In 2016, the Indonesian government has established a peat restoration contingency program to prevent peatland fires through various programs, one of which is rewetting [8].

The rewetting efforts that have been carried out by the Indonesian government through the Peatland Restoration Agency are the construction of simple canal blocks in tertiary or quaternary canal with a river width of approximately 2 to 5 meters. To examine the impact of this simple canal blocks construction, research is required to analyze the impact of canal blocking on the changes in water table in peatlands in West Kalimantan.

\subsection{Research objective}

The objective of this research was to assess and evaluate changes in water table in peatlands after the construction of a canal block in West Kalimantan.

\subsection{Literature review}

\subsubsection{Peatland overview}

Peat is a wetland ecosystem characterized by the accumulation of organic materials that lasts for a long time [9]. This accumulation occurs due to the decomposition rate which is much slower than the rate of accumulation of organic matter contained in the wetland forests. The process of peat formation almost always occurs in waterlogged forests, producing organic materials in large quantities.

Peatland is a land derived from organic materials and vegetations contained thereon, formed in areas with low topography, with high rainfall or in areas where the temperature is very low. Peat soils have a high content of organic matter ( $>12 \% \mathrm{C}$ carbon) [5]. Peat soils are classified as histosol in FAO-UNESCO Soil Classification System (1994), which are those containing organic matter higher than 30 percent, in layers as thick as $40 \mathrm{~cm}$ or more, in the top $80 \mathrm{~cm}$ of the soil profile.

Tropical peat is generally reddish brown to dark brown (dark) depending on the decomposition stage. Peat has a characteristic that is not shared by other types of soil, where peat is able to absorb water with a very high volume. The physical properties of peat in Wajok Hilir Village are histosol and associated with alluvial soils, because of its location in the coastal area [2].

The total porosity of peat ranges from 75 to $95 \%$ [10]. Roots of trees and forest plants form air cavities and porosity of soils that naturally have greater water retention capability compared to area that is not covered with vegetation [11]. Peat ecosystem in Indonesia stores about $57 \mathrm{Gt}$ of carbon [12]. The degradation of peat ecosystem is due to changes in land use into plantations, industrial tree plantations and farmland. This causes the release of one of the greenhouse gases into the atmosphere, which accelerates global climate change $[5]$. 
Land subsidence occurring in peatlands is highly dependent on existing activities on peatlands and nearby areas. The severity of the subsidence is influenced by the level of peat maturity, the age of reclamation, and the thickness of the peat layer; Fibric peat experiences greater subsidence than hemic and sapric peat. In order to minimize the occurrence of subsidence, things that have to ensure of is to maintain waterlogged condition or to maintain the water level at the relevant level, typically less than $40 \mathrm{~cm}$ [4].

\subsubsection{Water management on peat swamp land}

Drainage is a prerequisite for agricultural activity, although it is not an easy thing to do given the nature of the peat that can experience shrinkage and irreversible drying due to the drainage. Therefore, prior to reclamation of peatland, it is necessary to identify the specific nature of peat, its role and function for the environment [10]. A good drainage for peat agriculture is the drainage that retains critical water limit for peat, without causing harm to crops that will affect crop productivity.

The dimension of drainage canal varies depending on the soil's natural condition and the intensity of rainfall. High rainfall (4000-5000 mm per year) [10] requires a relatively large drainage system to minimize the effects of flooding on land. However the depth of the canal needs to consider the water level required to keep overdrain from occurring [4].

After the creation of drainage and peatland clearing, subsidence is generally relatively rapid, resulting in a decline in the soil surface. Subsidence and decomposition of organic matter can cause problems if the minerals under the peat layer consist of pyrite or quartz sand rise to the surface. The low bulk density resulted in low bearing capacity of peat soil, so the processing of the soil is difficult to do mechanically or with livestock. Low holding ability is also a problem for planting trees or seasonal plants susceptible to lodgings [10].

Water management is the key to successful agricultural development in peatlands. Water management in peat swamps is primarily intended to maintain soil moisture during dry season, to prevent flooding during rainy season, to wash toxic compounds such as organic acids and $\mathrm{H}_{2} \mathrm{SO}_{4}$, as well as to control pests.

Several possible mechanisms for water management on peatlands are as follows:

1. Blocking the canal on peatland

2. Building sluice gates on peatlands

3. Creating pond as a water reservoir on peatlands

4. Establishing long storage on existing canals in peatlands [13] by installing canal blocks.

\section{Methodology}

\subsection{Study area}

This research was conducted in Wajok Hilir Village, Siantan District, Mempawah Regency. Wajok Hilir Village is approximately in the position of S $0.0793^{\circ}$, E $109.3188^{\circ}$, which is located $\pm 11 \mathrm{~km}$ to the Northwest from the Capital of Pontianak, West Kalimantan Province (Figure 1). Wajok Hilir Village is affected by tides. Wajok Hilir Village has long been endeavored by most local people as agricultural land. Wajok Hilir Village is a region dominated by peat swamp, thus Wajok Hilir Village is one of the target villages of a program by Indonesia's Peatland Restoration Agency, Construction of peat rewetting infrastructure: canal block in 2017.

The average rainfall of Siantan District in 2015 ranges from 5.1 to. 304.1 millimeters. The highest average monthly rainfall occurred in January, while September was the lowest rainfall in Siantan District, which was only $5.1 \mathrm{~mm}$. The number of rainy days in Siantan 
District ranges from 6 to 26 rainy days with January as the month that has the highest number of rainy days for 26 rainy days. Meanwhile, the lowest number of rainy days occurred in September with rainy days of 6 [14].

The village of Wajok Hilir has high rainfall potential and is affected by tides. Thus peatlands in Wajok Hilir village are not supposed to experience drought. This is due to the influence of tidal sea water, where ground water remains available on land even though it does not rain. However, this is in contrast to the fact that the Wajok Hilir village often experiences fires during dry season, due to the dry land. It is necessary to find out the impact of rewetting efforts promoted by the government through the construction of a simple canal blocks, on the stability of water table in the peatlands, especially Wajok Hilir Village as the research location. Photos of canal block that have been built in the field can be seen in Figure 2.

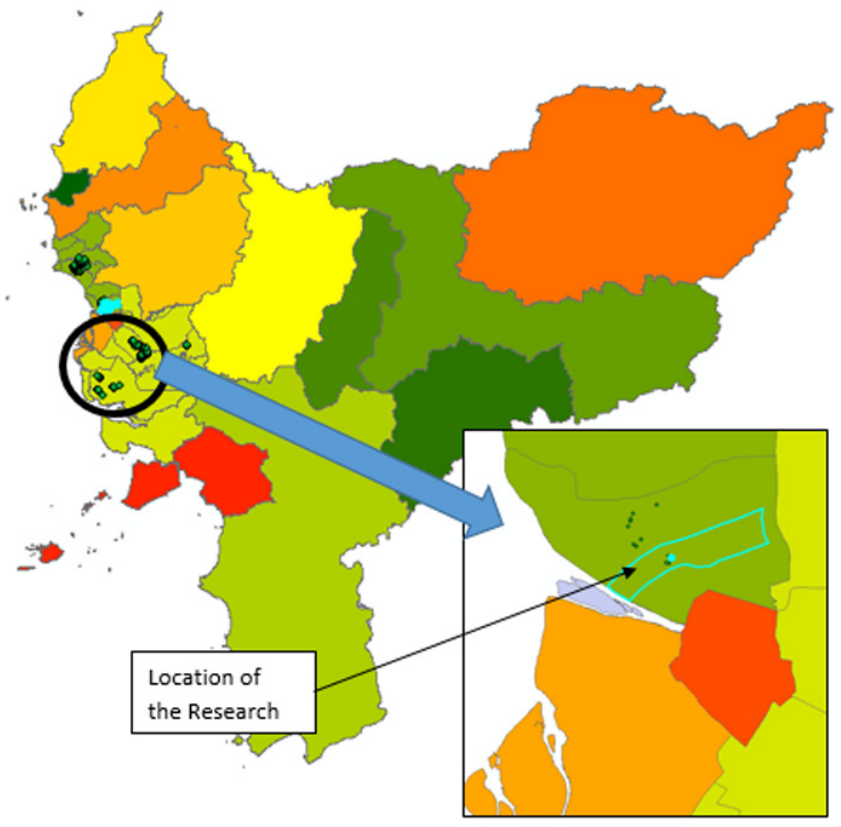

Fig. 1. Orientation of Wajok Hilir Village as a study area in West Kalimantan Province, Indonesia
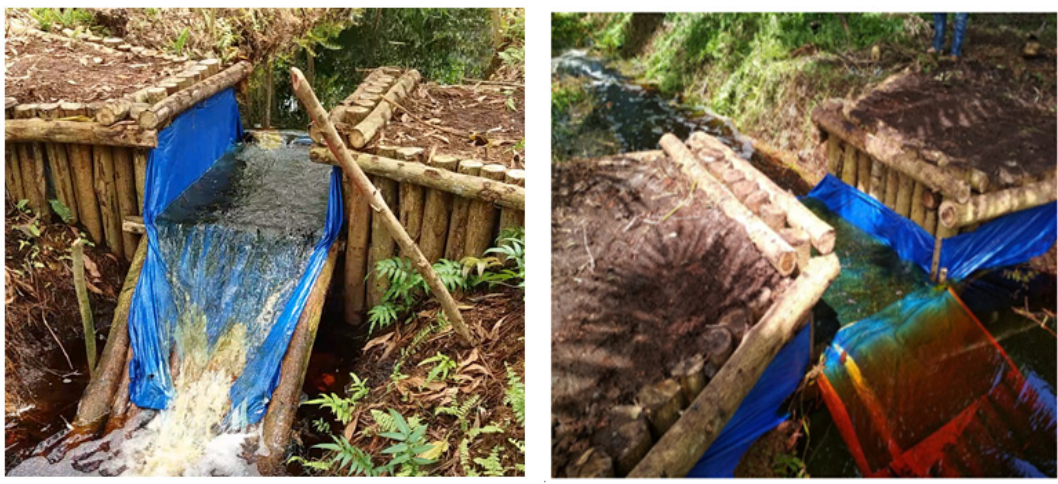

Fig. 2. Construction of canal block in Wajok Hilir Village, Documentation on January, 2018 


\subsection{Observation time}

Wajok Hilir Village is a tidal influenced village, which affects the water level in Wajok Hilir Village. Based on this condition, the research was conducted by observing the water table in the field by taking the periodic time of the tides into account. Observations were made from February to March 2018.

\subsection{Data collection method}

Collection of water level and water table data were done every day in the morning (at 06.00 a.m.) and afternoon (at 06.00 p.m.). Data were taken by reading the water level elevation on a peil scale or piezometer on peatland.

Measurements were made at several points of observation that may represent the water level around the land where canal block is built and surrounding areas where canal block is not built. Observations were also made by comparing the location around the tertiary canal with the location around the quaternary canal.

\section{Results and discussion}

The results of water table observation in peatland on canal where canal block is built and not built, show the difference of fluctuation of water level during 1 tidal periodic, that land surrounding canal where canal block is installed on have smaller water fluctuation compared to water table around the canal which are freely drain out the water (with no canal block). These data can be seen in Table 1. Measurement points and location of canal network and canal block can be seen in Figure 3.

In peatland where a canal block installed in a quaternary canal, a decrease in water table is averaging less than $30 \mathrm{~cm}$ (sample point 1). Whereas in peatland around a quaternary canal with no canal block, the average water table can reach more than $50 \mathrm{~cm}$ (sample point 2 ). This suggests that the construction of canal block helps retain water table longer in the land, by holding groundwater which was injected into peatlands by the tides.

Table 1. Average water table value at observation area.

\begin{tabular}{|c|c|c|c|c|}
\hline \multirow{2}{*}{ Item } & \multicolumn{4}{|c|}{ Observation Area } \\
\cline { 2 - 5 } & $\mathbf{1}$ & $\mathbf{2}$ & $\mathbf{3}$ & $\mathbf{4}$ \\
\hline $\max$ & 73,3 & 69,5 & 79,5 & 77,8 \\
\hline $\min$ & 45,5 & 14,5 & 45 & 22,5 \\
\hline interval & 27,8 & 55,0 & 34,5 & 55,3 \\
\hline
\end{tabular}

Note $: 1=$ location of the land around quaternary canal where the canal block is built

$2=$ location of the land around quaternary canal where the canal block is not built

$3=$ location of tertiary canal where the canal block isn't built

4 = location of the land around tertiary canal where the canal block is not built

In the tertiary canal (sample point 4), a canal whose dimensions are larger than the quaternary canals (sample point 2), the average maximum and minimum value of water table is consistently with a difference of around 8 centimeters during high tides and low tides. This is because the bigger the dimensions of the canal, the more volume of water that will be flow out of the canal, so that the existence of water on peatlands near tertiary canal will be further down below the surface than the area near quaternary canal. 


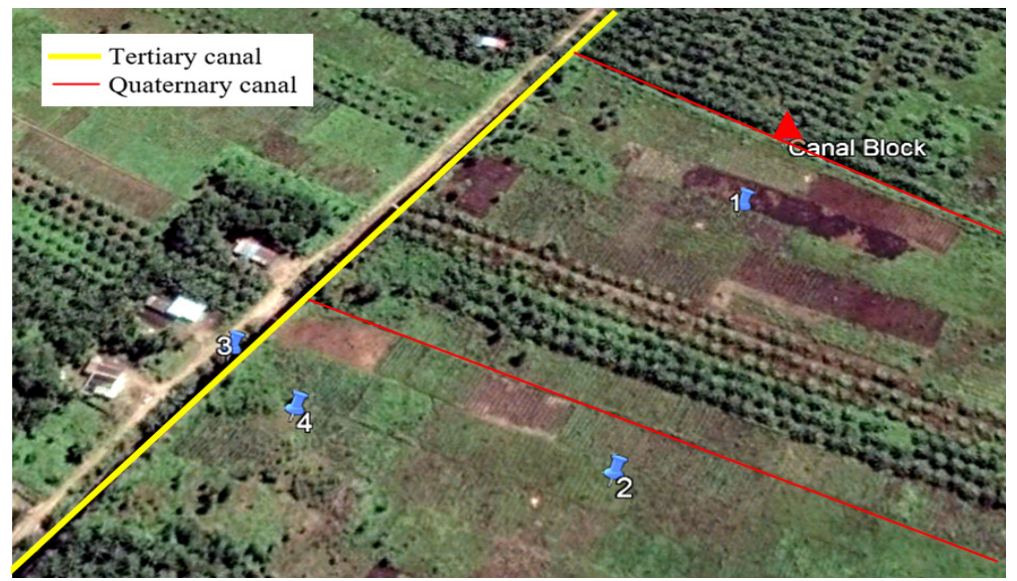

Fig. 3. Location of canal network, canal block, and measurement points

The relatively small water table fluctuations in the area affected by sea tides indicate that the construction of canal block in tertiary or quaternary canals can reduce the decline in water table in peatlands. Water table on peatlands is important to maintain because water table of less than $50 \mathrm{~cm}$ may reduce the dryness of the peat so the potential for land fires can be minimized.

The dry season can cause the water table to be far deep below the ground. Construction of canal block in quaternary or tertiary canals can restrain the rate of water out of the peatlands. By retaining water in the canal, the water table of less than $50 \mathrm{~cm}$ can be maintained.

Construction of canal block has been proven to maintain water table fluctuations. In addition to maintaining the water table, canal block may also be a water retainer in the canal, so that the canal can serve as a water container in the form of long storage. With a controlled water table, the possibility of land fires on peatlands caused by prolonged drought can be minimized.

Construction of the canal block in Central Kalimantan has also proven effective in raising the water content of peat soil. The study was conducted on peatland around Ahas River, on a location where canal block is not built, the water content of peat soil is only about $60 \%$, whereas on the location with canal block, the peat soil's moisture content is close to $250 \%$ [15].

Long-term peatland restoration is expected to restore hydrological function of peat. This is shown in the result of peatland restoration conducted in Porla and Vastkarr, Sweden. Both sites have previously degraded hydrological function of peat, but then returned to natural or semi-natural condition after restoration has been carried out in the form of peatland rewetting for 15 years [16]. The construction of canal block has also been proven to reduce carbon release and increase biodiversity [17].

\section{Conclusion and recommendation}

From the results of the study, it can be concluded that after the construction of canal blocks, the decline in water table in peatlands can be maintained. The construction of canal blocks may also be utilized to retain water in the canal, so that there will be a water reservoir in the canal that serves as a long storage, to meet the water needs for irrigation in the area surrounding the canal. In order to control water table in peatlands, construction of canal blocks is recommended to be built on tertiary and quaternary canals for all locations on peatlands. 
The Authors would like to express their appreciation to Indonesia's Peatland Restoration Agency for the construction of canal block which has become the object of this research. This research was conducted with financial support from Tanjungpura University. The authors would like to express gratitude to the reviewers who provide valuable comments and suggestions in order to improve the quality of this paper.

\section{References}

1. Euroconsult. Integrated Swamps Development Project IBRD Loan 3755-IND. (Departemen Pekerjaan Umum Kantor Wilayah Propinsi Kalimantan Barat P2DR, Pontianak, 1999)

2. R. Hazriani, T. O. Chandra. J. Agripr 6, 1, 779-786. (2010)

3. I. T. C. Wibisono, L. Siboro, I N. N. Suryadiputra. Panduan Rehabilitasi dan Teknik Silvikultur di Lahan Gambut. Wetlands (Wetlands InternationalIndonesia Programme and Wildlife Habitat Canada, Bogor, 2005)

4. R.W. Nusatara, Sudarmadji, T.S. Djohan, E. Haryono. J. Perkebunan \& Lahan Tropika. 2, 2, 58 - 70. (2013)

5. Page, S. J. Lestari 1, 1, 4-13. (2016)

6. E.C. Atwood, S. Englhart, E. Lorenz, W. Halle, W. Wiedemann, F. Siegert. PLoS ONE. 11,8, (2016)

7. A. Pribadi, G. Kurata. IOP Conf. Ser.: Earth Environ. Sci. 54. (2017)

8. A. Dohong, L. Cassiophea, S. Sutikno, B.L. Triadi, F. Wirada, P. Rengganis, L. Sigalingging. Modul Pelatihan Pembangunan Infrastruktur Pembasahan Gambut Sekat kanal Berbasis Masyarakat. (Kedeputian Bidang Konstruksi, Operasi dan Pemeliharaan, Badan Restorasi Gambut Republik Indonesia, Jakarta, 2017)

9. S. Najiyati, L. Muslihat, I. N. N. Suryadiputra. Panduan Pengelolaan Lahan Gambut untuk Pertanian Berkelanjutan. (Wetlands International-Indonesia Programme and Wildlife Habitat Canada, Bogor, 2005)

10. Hastin. E. N. C. Chotimah, 2002. "Pemanfaatan Lahan Gambut untuk Pertanian". http://rudyct.com/

11. A. Prayitno, A. Mencegah Kebakaran Hutan dan Lahan. Pengelolaan Lingkungan Berkelanjutan: Penguatan Program Pencegahan Kebakaran Hutan dan Lahan (Karhutla) Berbasis Masyarakat. Editor: A. Syahza., Suwondo, H. Gunawan. (U.R. Press, Pekanbaru, 65 - 78. 2015)

12. S. E. Page, J. O. Rieley, C. J. Bank. Global Change Biol. 17, 2, 798-818 (2011)

13. H. Herawati, S.B.Soeryamassoeka.. MATEC Web of Conf., SICEST 2016. 101 (2017).

14. Badan Pusat Statistik Kabupaten Pontianak. Kecamatan Siantan Dalam Angka 2017. (Badan Pusat Statistik Kabupaten Pontianak, Mempawah, 2017)

15. U. Fitriati, Rusliansyah, M. A. Ma'ruf. J. Appl. Environ. Biol. Sci. 7, 4, 111-117 (2017)

16. L. Lundin, T. Nilsson, S. Jordan, E. Lode, M. Strömgren. Wetlands Ecol. Manage. 25, 405-419 (2017) 
17. E. Grand-Clement, K. Anderson, D. Smith, M. Angus, D.J. Luscombe, N. Gatis, L.S. Bray, R.E. Brazier. J. of Env. Mngmnt. 161, 417-430 (2015) 